\title{
KULTURA GOSPODARCZA CYWILIZACJI ZACHODNIEJ - JEJ ISTOTA, SPRZECZNOŚCI I ZNACZENIE DLA ROZWOJU W SKALI GLOBALNEJ
}

ABSTRACT. Michalski Michał A., Kultura gospodarcza cywilizacji zachodniej - jej istota, sprzeczności $i$ znaczenie dla rozwoju w skali globalnej [The economic culture of the Western civilization - its essence, contradictions and role in the global development] edited by W. Banach - "Człowiek i Społeczeństwo", vol. XXXVIII, Poznań 2014, pp. 233-252, Adam Mickiewicz University Press. ISBN 97883-232-2791-5. ISSN 0239-3271.

The article presents an analysis of economic culture of the Western civilization in the context of its current shape and condition. Although this topic has already been chosen as the subject of research in the past, in this paper the stress is put on those aspects that do not seem to be very popular. To look at the uniqueness of the Western civilization in the context of a globalized world may seem incorrect to some extent, but in our opinion it is still necessary if we want to explore and to discover the sources of unprecedented growth and development that not only the West have benefited from. The article thereby contributes to the field of the research of the impact of culture on the socioeconomic order. The paper therefore seeks to offer an explanation of the specific path that the Western civilization has followed, because it is important in the context of the future dilemmas of global society, which needs to find solutions to its different challenges and problems. Besides discussing the contribution of such recognized authors as Max Weber and Peter L. Berger, the article analyses the role of mediating structures (with special reference to the family) and cultural contradictions which seriously influence the shape and condition of the West these days.

Michał A. Michalski, Uniwersytet im. A. Mickiewicza w Poznaniu, Wydział Nauk Społecznych, Instytut Kulturoznawstwa, Zakład Etyki Gospodarczej, ul. Szamarzewskiego 89a, 60-568 Poznań, Poland.

Kultura jest ważna, niezwykle ważna. Może się jednak zmienić. Kultury są złożone. W danym momencie niektóre ich cechy wysunięte zostają na pierwszy plan i zdają się niepodważalne. A potem polityka i ekonomia ulegaja przemianom, a wówczas cechy te traca na znaczeniu, robiąc miejsce innym.

Fareed Zakaria ${ }^{1}$

\section{WSTĘP}

Może się wydawać, że próba scharakteryzowania i opisania kultury gospodarczej cywilizacji zachodniej jest zadaniem niezmiernie trudnym i zło-

${ }^{1}$ F. Zakaria, Koniec hegemonii Ameryki, przeł. S. Kroszczyński, Media Lazar NADIR, Warszawa 2009, s. 92-93. 
żonym. Uważam, że tak rzeczywiście jest. Pomimo to jestem zdania, iż próby takie należy podejmować, tym bardziej że już to czyniono wcześniej. Za każdym jednak razem postawienie tak interesującego pytania dokonuje się nie tylko $\mathrm{w}$ innym kontekście, ale także $\mathrm{w}$ innym celu. W przypadku niniejszego artykułu uwaga zostaje zwrócona zarówno na te czynniki i elementy wpływające na kształt kultury gospodarczej Zachodu, które bywały już w literaturze omawiane, jak i na te, które albo nie były w niej obecne w ogóle, albo pojawiały się tam tylko w sposób marginalny. Zdaję sobie sprawę, że obecnie omawianie odrębne jakiejś cywilizacji - a szczególnie w odróżnieniu od innych - może wydawać się niepotrzebne, a nawet niepopularne, szczególnie w kontekście tak wyraźnej dominacji narracji dotyczącej tworzenia globalnego ładu $\mathrm{w}$ wielu wymiarach, $\mathrm{w}$ tym także na poziomie gospodarczym. Uważam jednak, że nadal rozpoznania dotyczące poszczególnych konkretnych - regionów świata okazują się przydatne i istotne w pogłębianiu naszego rozumienia rzeczywistości i poszukiwaniu środków i sposobów na zapewnienie i podtrzymanie rozwoju współczesnych społeczeństw. $\mathrm{W}$ takim zresztą duchu prowadzone są, tak popularne $\mathrm{w}$ ostatnich latach, badania nad znaczeniem kultury dla gospodarki, które stanowią podstawową ramę badawczą w niniejszym opracowaniu.

Aby podjęte tu rozważania uczynić jak najbardziej zrozumiałymi, należy sprecyzować, w jaki sposób będą stosowane zasadnicze pojęcia zawarte w tytule. Chodzi przede wszystkim o terminy 'cywilizacja' i 'kultura', których wzajemny stosunek przybiera w literaturze postać dwojaką. Według jednego sposobu ich postrzegania są one traktowane i używane jak synonimy. Innym razem są odmiennie definiowane i starannie rozgraniczane, i w taki też sposób będą stosowane w tym artykule. Jeśli chodzi o sposób ich rozumienia, to termin 'cywilizacja' będzie definiowany jako „,...] swoisty zestaw przedmiotów materialnych, idei konstrukcyjnych czy inżynierskich zrealizowanych $w$ tych przedmiotach (a więc inaczej technologii) oraz umiejętności właściwego posługiwania się nimi (kompetencji praktycznych)"2, podczas, gdy 'kultura' oznaczać będzie „[...] duchowy kontekst (a nawet regulator) działań ludzkich [...]"3. Oznacza to więc, że cywilizacja to przede wszystkim sfera materialna składająca się z rozmaitych artefaktów o charakterze między innymi gospodarczym, technicznym czy organizacyjnym, podczas gdy kultura to domena niematerialna, na którą składają się wartości, ideały i symbole ${ }^{4}$. W związku z tym - w kontekście podejmowanych tu

\footnotetext{
2 P. Sztompka, Socjologia. Analiza społeczeństwa, Znak, Kraków 2005, s. 239-240.

3 J. Sójka, Kulturoznawca w świecie gospodarki, „Kultura Współczesna” 2008, nr 1(55), s. 7.

${ }^{4}$ Por. K. Krzysztofek, Cywilizacja: dwie optyki, Instytut Kultury, Warszawa 1991, s. 17. Por. także J. Kopania, Między buddyzmem a islamem, czyli przedwczesność chrześcijaństwa, [w:] Ekofilo-
} 
badań nad kulturą gospodarczą - warto stwierdzić za Kazimierzem Sosenką, że „[...] kultura jest traktowana jako mechanizm adaptacyjno-regulacyjny łączący jednostki ze strukturami gospodarczymi" 5 .

Zwrócenie uwagi na cywilizację zachodnią okazuje się istotne, gdyż można zasadnie stawiać pytanie o to, w jakiej kondycji jest ona i jej kultura gospodarcza obecnie i czy nadal można spodziewać się, iż stanowić będzie ona - jak to było $\mathrm{w}$ przeszłości - ważną inspirację dla rozwoju w skali globalnej. Czytelnik rozważań tu podejmowanych zapewne odniesie wrażenie, że ich autor nie zajmuje względem cywilizacji i kultury Zachodu stanowiska neutralnego, ale że jego stosunek jest pozytywny. Jest tak w istocie, co jednakże nie pozwala zignorować wielu faktów i zagadnień, które mogą niepokoić, martwić, a niekiedy nawet zasługiwać wprost na ocenienie ich w sposób negatywny.

\section{PRÓBA ZDEFINIOWANIA CYWILIZACJI ZACHODNIEJ I JEJ KULTURY GOSPODARCZEJ}

W tym miejscu przechodzę do próby opisania specyfiki tej formacji społecznej, którą umownie określa się mianem Zachodu. Zdając sobie sprawę, że jest to zadanie wielce wymagające, uważam jego podjęcie za konieczne, by choćby w zarysie ukazać, na ile ścieżka rozwoju w tym wypadku była związana z konkretnym rodzajem rozstrzygnięć na poziomie tego, co określiłem wcześniej mianem kultury gospodarczej, stanowiącej element szerszego tła kulturowego. Chodzi więc o to, by pochylić się nad zjawiskiem, które dotyczy tego, iż świat zachodni podjął bardzo ambitną - i na pewno odważną - próbę budowy porządku społecznego, w którym pożądanym standardem miał być dobrobyt, a problemy tak powszechne w przeszłości jak wysoka śmiertelność i bieda miały być skutecznie przezwyciężone. Środkiem ku takiej rzeczywistości miały zaś być kapitalistyczna gospodarka rynkowa $\mathrm{w}$ wymiarze ekonomicznym i ustrój demokratyczny w wymiarze politycznym. Dla uwypuklenia szczególnego charakteru tego przedsięwzięcia warto przypomnieć, że wcześniejsza sytuacja egzystencjalna ludzkości nacechowana była znacznymi wahaniami koniunktury gospodarczej i związaną z nimi zmiennością dostępności dóbr, co $\mathrm{w}$ dużym stopniu zależne było od warunków naturalnych, wobec których człowiek w wielu wypad-

zofia, bioetyka, etyka biznesu. Aktualne problemy wspótczesności, red. J. Jaroń, Wydawnictwo Akademii Podlaskiej, Siedlce 2004, s. 203.

${ }^{5}$ K. Sosenko, Ekonomia w perspektywie aksjologicznej, Wydawnictwo Akademii Ekonomicznej w Krakowie, Kraków 1998, s. 70. 
kach pozostawał bezsilny. Jeśli chodzi o sposób rozumienia cywilizacji zachodniej, to używając tego terminu, mam na myśli te regiony, gdzie dominuje osobowa wizja człowieka wywodząca się z - wspartej elementami helleńskimi i rzymskimi - tradycji judeo-chrześcijańskiej, kapitalistyczny system gospodarczy oparty na mechanizmie rynkowym oraz demokracja jako system polityczny. Zdaję sobie zarazem sprawę, że rzeczywistość objęta tym pojęciem stanowi całość zróżnicowaną wewnętrznie, a i nierzadko nacechowaną sprzecznymi tendencjami. Także ze względu na historyczne przemiany poszczególnych krajów czy regionów - niekiedy bardzo radykalne, np. pod względem ustroju gospodarczego - należy zgodzić się na pewną umowność $\mathrm{w}$ operowaniu opisywanym tu terminem.

Poszukując odpowiedzi na pytanie o istotne elementy składowe zachodniej kultury gospodarczej, warto powrócić do propozycji Maxa Webera. Autor ten w pracy pt. Osobliwości kultury zachodniej stawia zasadnicze z interesującego nas punktu widzenia pytanie o to, „,...] jaki splot okoliczności doprowadził do tego, że właśnie na ziemi Zachodu, i tylko tutaj, powstały zjawiska, które - jak to sobie przynajmniej chętnie wyobrażamy - nabierają w swym rozwoju uniwersalnego znaczenia i ważności?"6. Rozważając powyższą kwestię, dokonuje on zestawienia tych elementów, które można uznać za specyficzne dla Zachodu, nie tyle pod względem ich obecności w ogóle, ile ich umiejscowienia i zastosowania w osobliwy sposób i w szczególnym kontekście ${ }^{7}$. Rozpoczyna ich wyliczanie od nauki, która oczywiście w różnych formach i intensywności występowała również w innych regionach świata, jednak w świecie zachodnim została zracjonalizowana i usystematyzowana na sposób wcześniej niespotykany ${ }^{8}$. To samo dotyczy systemu edukacji, który stał się sferą formacji i kształcenia zawodowych specjalistów i urzędników. To z kolei przyczyniło się do rozwoju kolejnego elementu specyficznego dla Zachodu, jakim jest urzędnicza organizacja, na której oparte jest funkcjonowanie społeczeństwa $\mathrm{w}$ takich sferach, jak polityka, technika czy gospodarka ${ }^{9}$. Z tym wiąże się natomiast stanowa struktura państwa, które

${ }^{6}$ M. Weber, Osobliwości kultury zachodniej, [w:] idem, Szkice z socjologii religii, przeł. J. Prokopiuk, H. Wandowski, Książka i Wiedza, Warszawa 1984, s. 70.

7 Oczywiście, zdaję sobie dobrze sprawę, że kwestia wyjątkowości ścieżki rozwoju cywilizacji zachodniej i jej ocena jest przedmiotem sporu. Por. np. D.S. Landes, Bogactwo i nędza narodów. Dlaczego jedni sa tak bogaci, a inni tak ubodzy, przeł. H. Jankowska, Warszawskie Wydawnictwo Literackie MUZA SA, Warszawa 2000; T.E. Woods Jr., Jak Kościót katolicki zbudowat zachodnia cywilizacje, przeł. G. Kucharczyk, Wydawnictwo AA, Kraków 2006; J. Goody, Kapitalizm i nowoczesność, przeł. M. Turowski, Wydawnictwo Akademickie Dialog, Warszawa 2006; idem, Kradzież historii, przeł. J. Dobrowolski, Wydawnictwo Naukowe PWN, Warszawa 2009.

8 Por. M. Weber, Osobliwości..., s. 70-71.

${ }^{9}$ Por. ibidem, s. 72 . 
jako polityczna instytucja wyposażona w system prawny i regulacyjny jest kolejnym elementem typowym właśnie dla Zachodu ${ }^{10}$. Następnym osiągnięciem wskazywanym przez Webera jest kapitalistyczny system gospodarczy, który uczony określa mianem dominującej siły kształtującej nowoczesne życie ${ }^{11}$. Zwraca przy tym uwagę, iż kapitalizm nie jest tożsamy z dążeniem do zysku czy pragnieniem zarobku, które nie są wyłącznie domeną ludzi Zachodu. Stwierdza on natomiast, że z istotą tego systemu związane jest raczej racjonalne panowanie nad impulsami chciwości, a zysk ma być efektem systematycznego funkcjonowania „racjonalnego zakładu kapitalistycznego"12 według reguł rentowności.

W tym miejscu, zanim przejdziemy do kolejnych elementów zachodniej kultury gospodarczej, zwróćmy jeszcze uwagę na element o znaczeniu podstawowym dla szczegółowych rozstrzygnięć kulturowych Zachodu. To, co zostało do tej pory zilustrowane na przykładach różnych form aktywności w obrębie społeczeństwa, ukazuje łącznie pewien szczególny stosunek człowieka do świata i rzeczywistości, którą współtworzy. Skoro, jak stwierdza Jacek Kochanowicz, kapitalizm i nowoczesna nauka doprowadziły do powstania społeczeństwa przemysłowego ${ }^{13}$, którego wpływ na kształt i standard życia można uznać za bezprecedensowy, to należy zadać pytanie o fundament, na którym te osiągnięcia stały się możliwe.

Odpowiedzi na to pytanie - wskazując na osobową koncepcję człowieka udziela Jerzy Kopania. Ten właśnie sposób myślenia - związany z perspektywą grecką, rzymską i chrześcijańską - stanowi fundament zachodniego postrzegania człowieka i społeczności przez niego tworzonych. Przywołany autor stwierdza, że "cywilizacja łacińska jest cywilizacją personalistyczną, tzn. człowieka rozumie jako podmiot i zarazem cel działań społecznych, przy czym dobro człowieka jest miarą i kryterium tych działań. Celem jest wszechstronny rozwój osoby ludzkiej, a więc i wolność, gdyż bez wolności nie ma rozwoju osobowego. Podkreślmy, że cywilizacja zachodnia jest jedyną cywilizacją posługującą się pojęciem godności osoby ludzkiej i pojęciem praw człowieka. Zarazem jednak personalizm podkreśla indywidualną odpowiedzialność człowieka, podczas gdy w cywilizacjach niepersonalistycznych preferuje się gromadność. Przykładem afirmacji ludzkiej wolności przez cywilizację łacińską jest fakt, że nikt prócz konkretnego człowieka nie

10 Por. ibidem, s. 72-73, 82.

11 Por. ibidem, s. 73.

12 Ibidem. Por. J. Kochanowicz, Trendy cywilizacyjne, [w:] Wymiary życia społecznego. Polska na przełomie XX $i$ XXI wieku, red. M. Marody, Wydawnictwo Naukowe Scholar, Warszawa 2002, s. 468.

${ }^{13}$ Por. ibidem. 
może ponosić odpowiedzialności za realizację i osiągnięcie celu życia człowieka"14.

Taki status jednostki ludzkiej nie tylko w perspektywie społecznej, ale także kosmicznej, stanowi niewątpliwie element zasadniczy dla zrozumienia specyfiki kultury Zachodu. Współtworzy on - używając sformułowania Webera - tę szczególną postać „racjonalizmu zachodniego”, z którego wyłania się „nowoczesny racjonalizm zachodni”"15. Ten ostatni - który nas tu szczególnie interesuje - pozostaje $\mathrm{w}$ relacji współzależności z tym, co Weber nazywa „określonym rodzajem praktyczno-racjonalnego sposobu życia”16. Oznacza to, że wynik gospodarowania według powyższych reguł racjonalności nie jest zależny tylko od poziomu techniki czy kształtu systemu prawnego, lecz jest także warunkowany rozstrzygnięciami kulturowymi wyznaczającymi określony sposób życia i związane z nim reguły. Tym samym w koncepcji Webera obecny jest trop, który pokazuje związek kultury gospodarczej z wartościami i normami obecnymi w sposobach organizowania i prowadzenia nie tylko podmiotów gospodarczych i składającego się z nich podsystemu społecznego, ale także pozagospodarczymi (w takim rozumieniu) aspektami wspomnianego już praktyczno-racjonalnego sposobu życia' ${ }^{17}$.

W tym miejscu uwaga zostanie zwrócona na kolejne szczególne rysy tym razem o charakterze ekonomiczno-instytucjonalnym - kultury gospodarczej Zachodu, które uzasadniają przyznanie jej statusu szczególnego pod względem produktywności i wydajności. Jak stwierdził Berger, „kapitalizm przemysłowy wyzwolił największe $\mathrm{w}$ historii ludzkości moce produkcyjne. Jak dotąd, żaden inny system społeczno-gospodarczy nie był w stanie wyzwolić porównywalnych mocy produkcyjnych"18. Na zagadnienie to - co istotne - spogląda się tu nie tylko $\mathrm{w}$ aspekcie systemu kapitalistycznego, który został już zdefiniowany, ale także w szerszym kontekście, który jest równie interesujący. Obejmuje on między innymi rewolucję naukowo-techniczną, przeplatającą się z postępem systemu kapitalistycznego ${ }^{19}$. Jej podłoże, związane ze szczególnym statusem nauki i podejściem do niej, zostało już także naszkicowane.

Chcę teraz zwrócić uwagę na inne rozstrzygnięcia, które dotyczą bezpośrednio sposobu myślenia o gospodarowaniu i praktycznych rozwiązań na

14 J. Kopania, op. cit., s. 204.

15 Por. M. Weber, Osobliwości..., s. 83.

16 Por. ibidem.

17 Jednym z przykładów mogą być konkretne rozstrzygnięcia dotyczące funkcjonowania małżeństwa i rodziny w cywilizacji zachodniej, na co zostanie jeszcze zwrócona uwaga.

18 P.L. Berger, Rewolucja kapitalistyczna, przeł. Z. Simbierowicz, Oficyna Naukowa, Warszawa 1995, s. 79.

19 Por. ibidem. 
nim opartych. Ich przedstawienie rozpocznę od kapitalistycznego sposobu myślenia o aktywności gospodarczej, które zawiera w sobie kilka szczególnych cech. Po pierwsze, bazą takich działań jest racjonalny zakład (rozumiany jako ciągłe i celowe działanie określonego rodzaju), który oddziela się od gospodarstwa domowego. Po drugie, gospodarowanie $\mathrm{w}$ taki sposób nastawione jest na osiąganie rentowności, czyli stale odnawialnego zysku, który zapewnia trwałość. Po trzecie, interakcja pomiędzy stronami procesu gospodarczego dokonuje się na zasadach pokojowej wymiany, której towarzyszy oczekiwanie osiągnięcia wymiernych korzyści. Po czwarte, w taki sposób podejmowanym aktom gospodarczym towarzyszy szacowanie wartości środków prowadzące do określenia kapitału oraz stosowanie rachunku kapitałowego, który oznacza ocenianie oraz kontrolowanie szans i efektów dotyczących zarobku na początku i na końcu danego przedsięwzięcia. Wiąże się to z rozwojem kolejnej cechy wyróżniającej kapitalistyczny sposób gospodarowania, jaką jest racjonalna buchalteria ${ }^{20}$.

Weber - wyliczając te elementy kultury gospodarczej Zachodu - podkreśla jednocześnie, że w takim sensie cechy i przykłady kapitalistycznego sposobu gospodarowania obecne były także w obrębie innych cywilizacji. To, co jest jednak wyjątkowe, to fakt, że "[...] tylko na Zachodzie zjawiska te osiągnęły istotne znaczenie, wydając różne rodzaje, formy i kierunki kapitalizmu, które gdzie indziej nigdy nie powstały. Na całym świecie istnieli kupcy: wielcy i detaliczni, lokalni i działający na dużych obszarach, istniało pożyczkodawstwo wszelkiego rodzaju, banki spełniające najróżniejsze funkcje, ale $\mathrm{w}$ istocie podobne do funkcji, jakie spełniały banki w naszym XVI wieku; morskie pożyczkodawstwo, commendy i stowarzyszenia commendowe miały także charakter zakładów i istniały wszędzie. [...] Od czasów nowożytnych zna jednak Zachód całkowicie inny i nigdzie na świecie nie rozwinięty rodzaj kapitalizmu: racjonalno-kapitalistyczną organizację (formalnie) wolnej pracy. Gdzie indziej istniały tylko zarodki tego rodzaju kapitali$\mathrm{zmu}^{\prime \prime 2}$.

Aby zrozumieć ten swoisty fenomen, warto przywołać tu stwierdzenie dotyczące personalistycznego charakteru kultury zachodniej, gdyż w takim kontekście można lepiej zrozumieć, w jaki sposób koncepcja człowieka przyczyniła się do takiego właśnie rozwoju owej cywilizacji. Można stwierdzić, że to taki sposób myślenia utorował drogę wolnej pracy, własności22,

${ }^{20}$ Por. M. Weber, Osobliwości..., s. 73-80.

${ }^{21}$ Ibidem, s. 78-79.

22 Por. H. de Soto, Rynek działa tylko na Zachodzie, przeł. Ł. Sommer, "Gazeta Wyborcza” 18.01.2001, s. 13, oraz R. Pipes, Wtasność a wolność, przeł. L. Niedzielski, MUZA SA, Warszawa 2000. 
a w sensie wymiany - wolnej konsumpcji i redystrybucji. Z pewnością warto także wspomnieć o procesie modernizacji, która ma wyraźny związek z rewolucją przemysłową, gdyż jest rozumiana jako „[...] proces przekształcania się społeczeństw tradycyjnych wedle modelu kapitalistycznego społeczeństwa przemysłowego" 23 . Taki sposób rozumienia może sprzyjać koncentrowaniu się na przeobrażeniach materialnego poziomu życia, choć przecież modernizacja ma o wiele więcej wymiarów, takich jak organizacyjny, technologiczny, polityczny, psychologiczny, ideologiczny czy kulturowy. Oznacza więc ona wielowymiarowy proces przejścia od społeczeństwa tradycyjnego do nowoczesnego, które w sposób zasadniczy różni się od formacji je poprzedzającej. Jak pisze Berger, zwracając uwagę na istotny w kontekście modernizacji proces 'różnicowania się', „,...] społeczeństwo nowożytne podlega rozczłonkowaniu, dzieląc się na różne instytucje, które we wcześniejszych okresach historii były zintegrowane w jednej instytucji (np. «funkcje» pokrewieństwa zostały rozdzielone między odrębne instytucje społeczne, gospodarcze i polityczne)" 24 . W rezultacie wraz z procesami modernizacyjnymi pojawiają się zarówno korzyści, jak i problemy. W tym miejscu zatem - odnosząc się przede wszystkim do tych ostatnich - spróbuję scharakteryzować aktualną kondycję cywilizacji zachodniej.

\section{WSPÓŁCZESNY KONTEKST CYWILIZACYJNY ZACHODU A KONDYCJA KULTURY}

Jeśli chodzi o wspomniany już charakter tego, co można by nazwać ambitnym projektem cywilizacyjnym Zachodu, to trzeba przyznać, że jego realizacja w znacznej mierze powiodła się, choć zarazem wygenerowała nowe problemy. Są one szczególnie widoczne w tzw. systemie integracji25, który można uznać za niezbędne podłoże, na którym dokonuje się odtwarzanie

${ }^{23}$ K. Krzysztofek, op. cit., s. 73.

24 P.L. Berger, op. cit., s. 70.

${ }^{25}$ Chodzi o takie jego rozumienie, które obecne jest u Bouldinga. Autor ten pisze, że „napotykamy [...] następujący problem: jeśli społeczeństwo biznesu ma przetrwać, musi rozwijać system i instytucje integrujące, przy czym instytucje dlań specyficzne (rynek, korporacje, banki itp.), mające $w$ zasadzie charakter instrumentalny, nie są zdolne do rozwijania silnych systemów integracji we własnym zakresie. Przeto instytucje rynkowe winny być uzupełnione zespołem instytucji integrujących, takich jak rodzina, Kościół, szkoła i naród, które rozwijają indywidualne systemy wartości, zasadzające się na miłości, samopoświęceniu, identyfikacji z celami pozaosobistymi oraz altruizmie. [...] Społeczeństwo, które poświęca nieproporcjonalnie dużą część swego życia i energii systemowi wymiany, może doprowadzić do podważenia tego systemu", K.E. Boulding, Etyka i biznes, [w:] Ponad ekonomiq, red. i przeł. J. Grosfeld, PIW, Warszawa 1985, s. 68-69. 
i przekaz ładu społeczno-kulturowego. Istotną sferą, w jakiej się to dokonuje, jest rodzina, i to na jej przykładzie można ukazać zasygnalizowany problem. Jest rzeczą oczywistą, że aby mówić o jakimkolwiek rozwoju - także gospodarczym - muszą zostać spełnione określone warunki, wśród których wskazać należy tak podstawowy, jak zapewnienie biologicznej odtwarzalności i ciągłości socjalizacji w społeczeństwie. Okazuje się jednak, iż pod tym względem - za sprawą kondycji małżeństw i rodzin - analizowana tu cywilizacja staje obecnie wobec poważnych trudności. W odniesieniu do przemian w tej sferze następujący pogląd ujawnił Gary S. Becker, ukazując zarazem ich gospodarczy kontekst. Pisał on w roku 1993, że „rodzina w świecie zachodnim uległa radykalnym zmianom - niektórzy twierdzą wręcz, że została niemalże zniszczona - przez wydarzenia ostatnich trzech dekad. Szybki wzrost wskaźników rozwodów znacznie powiększył liczbę gospodarstw domowych kierowanych przez kobiety i liczbę dzieci dorastających $\mathrm{w}$ gospodarstwach domowych $\mathrm{z}$ jednym tylko rodzicem. Duży wzrost udziału zamężnych kobiet $\mathrm{w}$ sile roboczej, włączając $\mathrm{w}$ to matki małych dzieci, ograniczył kontakt między dziećmi i ich matkami i przyczynił się do konfliktu pomiędzy płciami zarówno na polu zatrudnienia, jak i małżeństwa. Szybki spadek wskaźników urodzeń zredukował rozmiary rodziny i przyczynił się do wzrostu wskaźników rozwodów i udziału zamężnych kobiet $\mathrm{w}$ sile roboczej. Inaczej mówiąc, upowszechnianie się rozwodów i aktywności zawodowej wpłynęło na osłabienie pragnienia posiadania dużych rodzin" 26 .

Mamy więc do czynienia $\mathrm{z}$ sytuacją, gdy równolegle z przemianami trwałości i dzietności rodzin rozgrywają się wydarzenia wskazujące na osłabienie koniunktury gospodarczej, które w sposób szczególny ujawniły się w postaci kryzysu, zapoczątkowanego w roku 2007. Wśród wyjaśnień jego przebiegu pojawiały się także te, które przywoływały kontekst demograficzny. W jednej z publikacji z tego zakresu - analizującej współzależność zmian demograficznych i wzrostu gospodarczego w Unii Europejskiej pojawia się stwierdzenie, że zestawienie ekonometrycznych szacunków z prognozami Eurostatu dotyczącymi wielkości populacji wskazuje, iż trudno będzie uniknąć spadku PKB, a będzie on silniejszy w przypadku tych scenariuszy demograficznych, $\mathrm{w}$ których wystąpi wolny wzrost albo nawet spadek liczby pracowników ${ }^{27}$. W ostatnim czasie takie wahania PKB już się

${ }^{26}$ G.S. Becker, Treatise on the Family, Harvard University Press, Cambridge, MA-London 1993, s. 1. Por. T. Szlendak, Socjologia rodziny. Ewolucja, historia, zróżnicowanie, Wydawnictwo Naukowe PWN, Warszawa 2010, s. 366-377.

27 Por. The Relationship Between Demographic Change and Economic Growth in the EU, eds A. Prskawetz, T. Lindh, Research Report 32, Vienna Institute of Demography, July 2007, s. 99. 
zresztą ujawniły - z wyraźną tendencją zniżkową w roku 2012 - w niektórych krajach (szczególnie europejskich) tradycyjnie kojarzonych z cywilizacją zachodnią ${ }^{28}$. Co ciekawe, w większości tych krajów poprzedzone to było spadkiem dzietności w roku 2011 w porównaniu z rokiem $2010^{29}$.

Skutki wspomnianych przemian $\mathrm{w}$ funkcjonowaniu rodziny są dostrzegalne między innymi w sferze ubezpieczeń społecznych, której stabilność i wydolność stoi obecnie $\mathrm{w}$ wielu państwach pod znakiem zapytania, szczególnie gdy chodzi o systemy emerytalne ${ }^{30}$. Dotyczy to $\mathrm{w}$ głównej mierze tych spośród nich, które oparte są na zasadzie solidarności międzypokoleniowej. $\mathrm{W}$ ich wypadku niewystarczający przyrost naturalny stanowi bezpośrednie zagrożenie dla płynności całego systemu, gdyż jeśli w przyszłości będzie zbyt mało osób wypracowujących środki, z których wypłacane są bieżące emerytury, to ci, dla których stanowią one źródło utrzymania, narażeni są wprost na brak środków do życia. Propozycją, która ma zmniejszać ryzyko, jakie jest wpisane $\mathrm{w}$ powyższy model systemu emerytalnego, jest tzw. emerytura kapitałowa, opierająca się na pomnażaniu środków wpłacanych na indywidualne konta emerytalne.

Oba wspomniane rozwiązania mają swoje wady i zalety i można by oczywiście podjąć dyskusję, które z nich jest lepsze. Nie to jest jednak moim celem, lecz zwrócenie uwagi na fakt, że w obu przypadkach ostatecznie fundamentem wszelkich świadczeń emerytalnych są środki finansowe wypracowywane przez ludzi, którzy stali się członkami społeczeństwa za pośrednictwem rodziny i których znaczna część żyje w tej właśnie grupie społecznej. Mówienie więc o tym, czy lepsza jest emerytura 'od państwa' czy 'z sektora prywatnego' zawiera w sobie istotny błąd. Polega on na tym, że te sfery w rzeczywistości zaledwie pośredniczą $\mathrm{w}$ dystrybucji środków, które tylko wtedy mogą zostać wypracowane, gdy rodzina spełnia swoje rozmaite funkcje, a wśród nich w tym wymiarze podkreślić należy funkcję prokreacyjną i socjalizacyjną.

${ }^{28}$ Spadek zanotowały m.in. takie kraje, jak Austria, Holandia, Niemcy, Hiszpania, Słowenia, Portugalia, Włochy, Irlandia, Grecja, Finlandia i Francja. Por. http://data.world bank.org/indicator/NY.GDP.MKTP.CD [dostęp: 17.01.2014].

${ }_{29}$ Por. http://data.worldbank.org/indicator/SP.DYN.TFRT.IN [dostęp: 17.01.2014]. Trzeba jednakże zaznaczyć, że zbieżność analizowanych tu procesów w czasie nie musi jednoznacznie potwierdzać ich współzależności. Warto przy tym pamiętać, iż skutki zmian demograficznych niekoniecznie muszą być zauważalne i odczuwalne w krótkiej perspektywie.

${ }^{30}$ Warto wskazać przynajmniej niektóre źródła ukazujące dyskusje dotyczące tej problematyki i nawiązujące do niej. Oto niektóre z nich: I. Ehrlich, F.T. Lui, Social Security, the Family, and Economic Growth, „Economic Inquiry” 1998, vol. XXXVI, July; P.A. Morrison, Demographic Links to Social Security, "Challenge” January-February 1982; J.J. Sztaudynger, W. Zaton, Kryzys gospodarczy a kryzys rodziny - analizy symulacyjne, „Prakseologia” 2010, nr 150. 
Gdyby spojrzeć na tę sytuację z perspektywy kultury, to na swój sposób kondycja demograficzna świata zachodniego ukazuje cywilizację, która nie jest nastawiona na odtwarzanie, a więc w konsekwencji i na przetrwanie. Oznacza to szczególny sposób traktowania cyklu życia, którego zależność od rytmu natury była tak wyraźna i silna w epoce przednowoczesnej, a wraz z nowoczesnością zaczęła się 'rozluźniać', w znacznym stopniu dzięki osiągnięciom naukowo-technicznym. Okazuje się więc, że proces marginalizowania znaczenia uwarunkowań biologicznych i ich wpływu na funkcjonowanie społeczeństwa postępuje. Jak stwierdza Castells, podejmując kwestię 'społecznej arytmii', „obecnie organizacyjne, technologiczne i kulturowe wydarzenia, charakterystyczne dla nowego, wyłaniającego się społeczeństwa, zdecydowanie podważają ten uporządkowany cykl życia, bez zastępowania go jakąkolwiek alternatywną sekwencją. Proponuje hipoteze, że spoteczeństwo sieciowe charakteryzuje załamanie rytmów, zarówno biologicznych, jak i społecznych, powiazanych z pojęciem cyklu życia" 31 .

Wyjaśnienie powyższej przemiany tylko poprzez sferę nauki, techniki i ich gospodarczych aplikacji uważam za niewystarczające. Chodzi o przeplatanie się elementów wywodzących się z kultur względem siebie opozycyjnych, co w konsekwencji prowadzi do problemów tu analizowanych. Chodzi mianowicie o fakt nakładania się na siebie elementów tego, na co zwracał uwagę Berger, a co nazwać można - w interesującym nas kontekście przeciwstawnymi kulturami gospodarczymi. W wyniku tego gospodarka Zachodu poddawana jest jednocześnie sprzecznym tendencjom, co skutkuje tym, że indywidualna samorealizacja konkuruje ze wspólnotową kooperacją, państwo opiekuńcze ściera się z wolnością, przedsiębiorczością i odpowiedzialnością obywateli, krótkoterminowy cykl koniunktury rynkowej rywalizuje z długofalowym procesem odtwarzania społeczeństwa, pragnienie zawarcia małżeństwa i założenia rodziny 'zmaga się' o czas z ambicją osiągnięcia określonego poziomu materialnego życia i zabezpieczenia socjalnego.

\section{KULTUROWE SPRZECZNOŚCI CYWILIZACJI ZACHODNIEJ}

Ponieważ nie jest możliwe, by wyczerpująco przeanalizować postawiony tu problem, dlatego ograniczę się do spojrzenia na analizowane tu zagadnienia z perspektywy kultury. Jestem bowiem zdania, że to właśnie na tym

31 M. Castells, Społeczeństwo sieci, przeł. M. Marody i in., Wydawnictwo Naukowe PWN, Warszawa 2007, s. 444. Por. P.L. Berger, Th. Luckmann, Spoteczne tworzenie rzeczywistości, przeł. J. Niżnik, Wydawnictwo Naukowe PWN, Warszawa 2010, s. 77-79. 
najgłębszym poziomie należy szukać wyjaśnienia i zrozumienia procesów oraz zmian zachodzących w realiach społeczno-gospodarczych. Jeśli chodzi o wyjątkowość cywilizacji Zachodu, która była przedmiotem opisu na poprzednich stronach, to miała ona $\mathrm{w}$ znacznym stopniu wydźwięk pozytywny, chociażby pod względem osiągnięć, które w sposób zasadniczy przyczyniły się do polepszenia warunków życia na masową skalę. Obecnie można odnieść wrażenie, iż uwagę przykuwają już nie te niewątpliwe osiągnięcia, lecz nierzadko związane $\mathrm{z}$ nimi zjawiska wzbudzające niepokój i dyskusje zarówno dotyczące ich genezy, jak i właściwych rozwiązań pojawiających się trudności ${ }^{32}$. Sytuację tę dobrze oddają słowa Ingleharta i Bakera, którzy stwierdzają, że „dziś niewielu byłoby skłonnych przypisywać moralną wyższość cywilizacji Zachodu, a gospodarki zachodnie nie są już traktowane jako rozwiązanie modelowe dla świata"33. Inni z kolei w sposób krytyczny oceniają obecną sytuację Zachodu jako paradoksalne połączenie materialnego nadrozwoju i duchowego ubóstwa ${ }^{34}$.

Oznacza to, że w obecnym kontekście kulturowym Zachodu obecne są zasadnicze sprzeczności, które znajdują swe odbicie w kształcie cywilizacji. Interesującą diagnozę w tym zakresie stawia Daniel Bell. Zauważa on, że problem, który nas tu interesuje, związany jest z tym, iż „, [...] trzy obszary ekonomia, polityka i kultura - podlegają trzem przeciwstawnym zasadom: wydajności w ekonomii, równości w polityce i samorealizacji (lub samogratyfikacji) - w kulturze. Konflikty w społeczeństwie zachodnim w ciągu ostatnich stu pięćdziesięciu lat miały swe źródło w napięciach wynikających $\mathrm{z}$ rozchodzenia się tych trzech obszarów" $w^{\prime \prime}$.

W tym miejscu warto zwrócić uwagę na jeden z przejawów tej anomii, dotyczący kosztów, jakie pojawiają się wraz z osiągnięciami w sferze technicznej i materialnej. Ma to związek ze wspomnianym już systemem inte-

32 „Pytanie: co dalej? - trapi ludzi zaniepokojonych tym, co się wokół nich dzieje. Niełatwo jest na to pytanie odpowiedzieć. Pojęcia, do których jeszcze niedawno się odwoływano i które wydawały się oczywiste - rozwój, postęp, racjonalizacja działań społecznych - tracą swą jednoznaczną wymowę. Wiemy dzisiaj, że lepsze bywa wrogiem dobrego, że innowacje pociągać mogą za sobą nieprzewidziane skutki, że ich koszty przerzucane są często na barki przyszłych pokoleń i że szybkie zmiany społeczne zakłócają równowagę, bez której społeczeństwa nie mogą normalnie funkcjonować", M. Hirszowicz, Stąd, ale dokąd? Spoteczeństwo u progu nowej ery, Wydawnictwo Sic!, Warszawa 2007, s. 266.

33 Por. R. Inglehart, W.E. Baker, Modernization, Cultural Change, and the Persistence of Traditional Values, „American Sociological Review” 2000, vol. 65, no. 1, February, s. 19-20.

${ }^{34}$ Por. P.B. Smith, M. Max-Neef, Economics Unmasked. From Power and Greed to Compassion and the Common Good, Green Books, Devon 2011, s. 19.

35 D. Bell, Kulturowe sprzeczności kapitalizmu, przeł. S. Amsterdamski, Wydawnictwo Naukowe PWN, Warszawa 1998, s. 32. Wydaje się, że w wyniku przekładu słowo 'ekonomia' zastąpiło wyraz 'gospodarka', co wpływa na znaczenie tej wypowiedzi. 
gracji, którego stan w coraz większym stopniu przyciąga zainteresowanie i pobudza do refleksji. W interesujący sposób analizują to w kontekście ładów transakcyjnych Bloch i Parry, którzy choć koncentrują się na wymiarze gospodarczym, to potwierdzają pośrednio wyjątkowość kultury zachodniej $\mathrm{w}$ ogóle ${ }^{36}$. Analizując funkcjonowanie sfery wymiany i roli pieniądza, wprowadzają oni rozróżnienie na krótko- i długoterminowe łady transakcyjne, określane także jako cykl krótko- i długoterminowy ${ }^{37}$. Podczas gdy pierwszy rodzaj odnosi się do tych relacji i wymian, które dokonywane są na sposób rynkowy, głównie według reguł indywidualnego współzawodnictwa, to drugi ład odnosi się do długofalowej reprodukcji ładu społecznego ${ }^{38}$. Założeniem towarzyszącym tej klasyfikacji jest przekonanie, że pożądanym stanem jest równowaga obu rodzajów ładu w społeczeństwie. Odnosząc to do kwestii anomii, którą tu analizuję, autorzy ci stawiają istotną diagnozę, pisząc, iż "to, co się stało unikalnego w kapitalistycznej ideologii, [...] polega na tym, że wartości sterujące krótkoterminowym ładem zostały wyartykułowane $\mathrm{w}$ postaci teorii długoterminowej reprodukcji. To, co nasza kultura (podobnie jak inne) stworzyła w obrębie oddzielnych i podporządkowanych domen, zostało, przynajmniej częściowo, doprowadzone do postaci teorii wszechogarniającego ładu - teorii, w której wyłącznie nieskrępowane, indywidualne przywary mogą przynieść publiczną korzyść" 39 .

Taki stan rzeczy w obrębie cywilizacji zachodniej bywa kojarzony ze zjawiskiem komercjalizacji, na której przykładzie można zobrazować sytuację interesującej nas tu kultury Zachodu. W odniesieniu do tego Andrzej Radomski pisze, że "dominacja praktyk gospodarczych i niesionych przez nie wartości spowodowała osłabienie roli i znaczenia praktyk regulowanych przez sferę symboliczną kultury. Światopoglądy uległy prywatyzacji (bądź zanikowi). Każdy potencjalnie może sobie tworzyć własne słowniki finalne. Wiele dziedzin na czele z nauką, której część dyscyplin badała poszczególne aspekty kultury symbolicznej, stanęło przed widmem «bezrobocia». Wolny rynek wkroczył do pozostałych praktyk. I w nich to upowszechniły się takie

36 Por. M. Bloch, J. Parry, Pieniądz i moralność wymiany, [w:] Badanie kultury. Elementy teorii antropologicznej, red. M. Kempny, E. Nowicka, Wydawnictwo Naukowe PWN, Warszawa 2005, s. 236.

37 Por. ibidem, s. 241-246.

38 Por. ibidem, s. 241.

${ }^{39}$ Ibidem, s. 247. Kontynuując, autorzy ci podają ważne zastrzeżenie: „Jednakże jest również możliwe, że zmiana pojęciowości była mniej radykalna i że to, co się naprawdę dokonało jak dawno temu sugerował esej Maussa Szkic o darze (1973) - polega na tym, że zachodnia ideologia podkreśliła odrębność dwóch cyklów do tego stopnia, że nie można sobie wyobrazić mechanizmów, dzięki którym są one wzajemnie połączone", ibidem. 
wartości, jak zysk, efektywność, skuteczność czy popularność. Krótko mówiąc: komercjalizacja" 40 .

Wiąże się to z problemem homogenizacji, a więc z tendencją do ujednolicania przestrzeni społecznej, która wydaje się charakterystyczna dla kultury nowoczesnej, prowadzącą między innymi w stronę urynkowienia przestrzeni społecznej. Proces ten, przejawiający się poprzez ujednolicanie różnych sfer w obrębie społeczeństwa, dotyka rozmaitych aspektów życia jego członków. Za jego przejawy można traktować między innymi takie zjawiska, jak zacieranie różnic między płciami, grupami wiekowymi, rolami społecznymi i rodzinnymi. Od razu można zauważyć, że jeśli symptomy te odniesiemy do mechanizmu rynkowego - który niekiedy bywa traktowany jako ich przyczyna - to okazuje się, że poprzez takie przemiany zwiększa się zasięg wymiany handlowej, gdyż grupy wcześniej z niej wyłączone (lub mające ograniczony dostęp do rynku z różnych względów) w tym nowym kontekście - poprzez owo specyficzne zatarcie granic - stają się potencjalnymi, a nierzadko faktycznymi konsumentami.

Dobrą ilustracją tej przemiany jest problem traktowania dziecka jako podmiotu rynkowego, przede wszystkim w zakresie konsumpcji. Można zauważyć, że tradycyjnie rola dziecka $\mathrm{w}$ rodzinie, która związana jest z oczekiwaniem posłuszeństwa i podporządkowania rodzicom, ogranicza dziecku dostępność do rozmaitych produktów i usług, nierzadko chroniąc je w ten sposób. Gdy jednak zakwestionowany zostaje status dziecka jako osoby, która nie może samodzielnie decydować o wszystkim, a promowany jest model partnerskich relacji rodzic-dziecko, to okazuje się, że trudniej znaleźć uzasadnienie dla podtrzymywania ograniczeń związanych ze sferą rynku ${ }^{41}$. W takiej sytuacji wspomniana wcześniej homogenizacja zaciera osobowe różnice pomiędzy uczestnikami wymiany i właściwie oznacza depersonalizację. Gdy zestawimy to z analizą Kopytoffa, który pokazuje, że wzrost homogenizacji prowadzi do regresu kultury, to właściwie należy uznać, iż przesadna homogenizacja staje się zagrożeniem dla samego człowieka. Autor ten, zwracając uwagę na to, że kultura umożliwia porządkowanie kognitywne świata, pisze, iż „ład osiąga się dzięki temu, że kultura za pomocą rozróżnień i klasyfikacji wydziela z wszechogarniającej heterogeniczności różne obszary wewnętrznie homogeniczne. Jednak jeżeli proces homogeni-

40 A. Radomski, Dyskurs kulturoznawczy a kultury wspótczesnych społeczności, „Kultura Współczesna" 2007, nr 1(51), s. 70.

41 Por. M.A. Michalski, Dzieci rynku... Rynek dzieci... Osoby czy zasoby?, [w:] Annales. Etyka $w$ życiu gospodarczym, t. 15, Salezjańska Wyższa Szkoła Ekonomii i Zarządzania, Łódź 2012, oraz B.R. Barber, Skonsumowani. Jak rynek psuje dzieci, infantylizuje dorostych i potyka obywateli, przeł. H. Jankowska, Warszawskie Wydawnictwo Literackie MUZA SA, Warszawa 2009. 


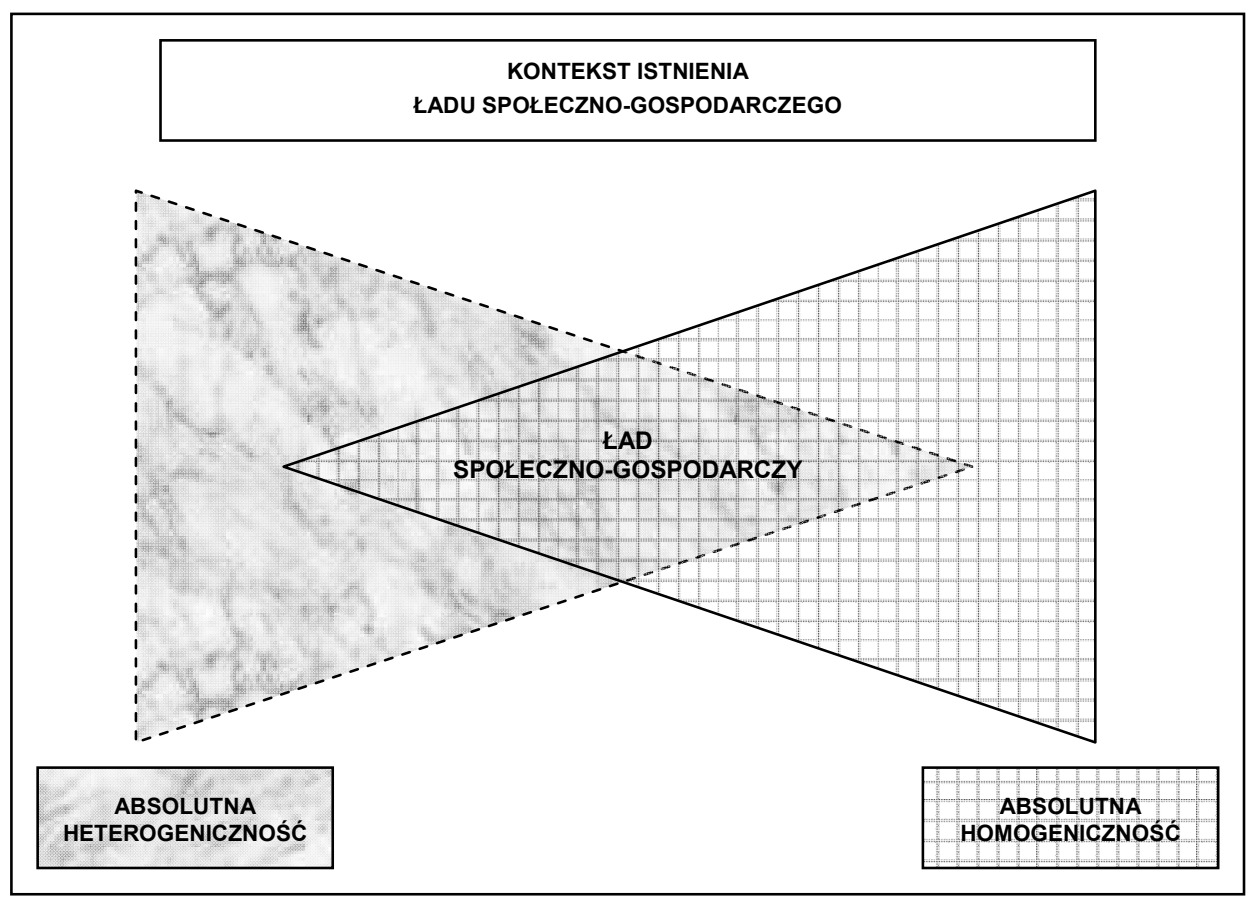

Rysunek. Ład społeczno-gospodarczy jako efekt harmonizowania przeciwstawnych tendencji w obrębie kultury

Opracowanie własne na podstawie: I. Kopytoff, op. cit., s. 254-255.

zacji posunie się zbyt daleko i postrzegany świat zacznie przybliżać się zbytnio do przeciwległego bieguna, co w przypadku rzeczy oznacza całkowite utowarowienie, podkopana zostaje funkcja kultury, polegająca na przeprowadzaniu kognitywnych rozróżnień" 42 .

Powyższy rysunek stanowi próbę przedstawienia kontekstu, w jakim tworzy się ład społeczno-gospodarczy, który cechować musi spójność, jeśli ma on być efektywny w swym funkcjonowaniu. Jeśli chodzi o jego rozumienie, to jest ono bliskie temu, co Amitai Etzioni określił mianem 'dobrego

42 I. Kopytoff, Kulturowa biografia rzeczy - utowarowienie jako proces, [w:] Badanie kultury..., s. 255. Z tej perspektywy można postawić pytanie, czy nie mamy do czynienia z regresem kulturowym, gdyż osiągnięte $\mathrm{w}$ ostatnich stuleciach (w mniej lub bardziej znacznej mierze i z większym lub mniejszym sukcesem) wyłączenie człowieka $\mathrm{z}$ bycia przedmiotem wymiany handlowej zdaje się ustępować ponownemu jego utowarowieniu, które w sprzyjających temu okolicznościach oznacza tendencję do rozszerzania zakresu wymiany towarowej. W konsekwencji człowiek współczesny znów stoi w obliczu zagrożenia stania się przedmiotem, a nie podmiotem wymiany. Por. ibidem, s. 249-250, 268, 272, oraz Ch. Delsol, Esej o człowieku późnej nowoczesności, przeł. M. Kowalska, Znak, Kraków 2003, s. 151. 
społeczeństwa', w którym ludzie traktują siebie nawzajem jako cele, a nie środki, i zarazem jako członków jednej społeczności, którą opisuje jako rodzinę znacznie poszerzoną (much extended family). Jeśli chodzi o kwestię ła$\mathrm{du}$, to takie społeczeństwo zachowuje odpowiednie proporcje pomiędzy aparatem państwowym, sferą rynkową i społecznością. Co istotne, realizacja tak rozumianego ładu wymaga współpracy tych trzech sfer, które zarazem pełnią względem siebie nawzajem funkcje kontrolne ${ }^{43}$. Jeśli zaś chodzi o dwie skrajne sytuacje - opisane na rysunku jako 'absolutna heterogeniczność' i 'absolutna homogeniczność - to prowadzić do nich będzie zaburzenie równowagi i współpracy, o których była mowa wcześniej.

W tym kontekście można stwierdzić, że równowaga (albo jej brak) zarówno pomiędzy sferą publiczną a prywatną, jak i w obrębie samej sfery prywatnej ma wpływ na kondycję kultury i ma związek ze spójnością społeczno-gospodarczą. W kontekście przywoływanej tu analizy społeczeństwa nowoczesnego w odniesieniu do cywilizacji zachodniej można stwierdzić, że jednym z jego zasadniczych problemów - i zarazem źródłem różnych napięć jest właśnie nierównowaga w wymienionych powyżej przestrzeniach. Objawia się ona przyznawaniem pierwszeństwa sferze obrotu towarowego i społecznie zorganizowanej pracy, które swym funkcjonowaniem odzwierciedlają raczej 'naturę' Gesellschaft niż Gemeinschaft. Oznacza to, że coraz większa część przestrzeni społecznej funkcjonuje według reguł racjonalności formalnej, o której pisał Weber44. To z kolei odsyła nas znów do problemu komercjalizacji, którego znaczenie $\mathrm{w}$ taki sposób komentują Teresa Bal-Woźniak i Michał Gabriel Woźniak: „Upowszechnianie instytucji wypierających altruizm, myślenie w kategoriach dobra wspólnego, godności osoby i jej podmiotowości oraz innych uniwersalnych wartości aksjologicznych utrwalonych $\mathrm{w}$ dziejach ludzkości, jest produktem komercjalizacji wszystkich sfer bytu ludzkiego"45. Autorzy zwracają na to uwagę w kontekście deficytu spójności społeczno-gospodarczej, który ich zdaniem domaga się

43 Por. A. Etzioni, For a Soft Moral Culture, „Kettering Review” 2001, vol. 19, no. 2, s. 37-38, http://www.gwu.edu/ ccps/etzioni/A285.pdf [dostęp: 2.10.2012].

${ }^{44} \mathrm{M}$. Weber, Gospodarka i społeczeństwo. Zarys socjologii rozumiejącej, przeł. D. Lachowska, Wydawnictwo Naukowe PWN, Warszawa 2002, s. 60.

45 T. Bal-Woźniak, M.G. Woźniak, Gospodarka Polski 1990-2011. Transformacja. Modernizacja. Spójność społeczno-ekonomiczna. Synteza, „Nierówności Społeczne a Wzrost Gospodarczy” 2011, z. 21, Uniwersytet Rzeszowski i Uniwersytet Ekonomiczny w Krakowie, Rzeszów-Kraków, s. 43. Potwierdza to także Kopytoff, który pisze: „W dużych skomercjalizowanych społeczeństwach istnienie wyrafinowanej technologii wymiany otwiera gospodarkę na zalew utowarowienia. We wszystkich współczesnych społeczeństwach przemysłowych, niezależnie od ich ideologii, utowarowienie i monetaryzacja wdzierają się - jawnie lub w postaci czarnego rynku niemal we wszystkie aspekty życia", I. Kopytoff, op. cit., s. 272. 
rewizji umowy społecznej $\mathrm{w}$ jej dotychczasowej formie ${ }^{46}$. To zaś możemy rozumieć szerzej, jako wezwanie do krytycznego pochylenia się nad obecnie dominującymi treściami kultury Zachodu.

Wydaje się więc, że w kontekście analizowanej tu kultury gospodarczej cywilizacji zachodniej istotnymi elementami, które należy brać pod uwagę, są - poza ważnymi instytucjami i narzędziami natury gospodarczej - rozstrzygnięcia dotyczące praktycznego sposobu życia na poziomie fundamentalnym zarówno dla reprodukcji biologicznej społeczeństwa, jak i dla odtwarzania oraz transmisji kultury gospodarczej.

Bez względu na to, w jakim kierunku podąży kultura gospodarcza Zachodu - a właściwie obecnie może powinno się już mówić o 'kulturach gospodarczych Zachodu' - jej wpływ na dzisiejszy obraz świata wydaje się niepodważalny. Wydaje się, że zasadnie można stwierdzić, iż jest czymś pozytywnym to, że sukces cywilizacyjny Zachodu - w wymiarze ogólnym dzięki jego kulturze, a w interesującym nas tu wymiarze dzięki kulturze gospodarczej - przyczynił się do tego, iż także inne regiony świata dziś doświadczają wzrostu i dobrobytu. Jak stwierdza Zakaria, komentując przemiany pozycji Stanów Zjednoczonych jako mocarstwa światowego, „komuś może wydawać się dziwne, że mówię tu o wzroście i dobrobycie, podczas gdy setki milionów wciąż muszą żyć w warunkach rozpaczliwej nędzy. Jednak w rzeczywistości liczba ludzi żyjących za dolara lub mniej dziennie spadła z 40 procent $\mathrm{w}$ roku 1981 do 18 procent populacji naszej planety w roku 2004, a w roku 2006 ludzie ci stanowili 12 procent ludności Ziemi. Sam tylko wzrost Chin przyczynił się do wydźwignięcia z ubóstwa ponad czterystu milionów ludzi. W krajach zamieszkanych przez 80 procent ludności planety stopa ubóstwa maleje. Te 50 krajów, które w największym stopniu dotknięte są klęską nędzy, rzeczywiście wymagają szczególnej troski. Jednak pozostałe 142 państwa - wliczając w to Chiny, Indie, Brazylię, Rosję, Indonezję, Turcję, Kenię i Republikę Południowej Afryki - stopniowo eliminują ten problem dzięki produktywnej i rozwijającej się gospodarce. Po raz pierwszy od zarania dziejów mamy do czynienia ze wzrostem, który odbywa się naprawdę na globalną skalę. Powstaje dzięki temu międzynarodowy system złożony z krajów położonych w najrozmaitszych zakątkach świata, które nie są już przedmiotami lub obserwatorami, lecz graczami i podmiotami" 47 .

Zapewne dokładne oszacowanie tego, w jakim stopniu do takiej sytuacji przyczyniła się cywilizacja zachodnia i jej - pod wieloma względami szcze-

\footnotetext{
46 Por. T. Bal-Woźniak, M.G. Woźniak, op. cit., s. 44.

${ }^{47}$ F. Zakaria, op. cit., s. 35.
} 
gólna - kultura gospodarcza, nie jest możliwe. Niemniej sądzę, że wielu z nas zgodzi się co do tego, iż wiele ważnych gospodarczo, i tak dziś rozpowszechnionych, osiągnięć naukowo-technicznych, instytucji społeczno-politycznych i wpisanych w nie rozstrzygnięć aksjonormatywnych ukształtowało się i udoskonaliło właśnie w łonie kultury i cywilizacji zachodniej. Ulegały one niekiedy twórczym adaptacjom i modyfikacjom, co nierzadko ukazywało ich jeszcze większy potencjał. Obserwowanie zaś i śledzenie tych, jakże często innowacyjnych, aplikacji oraz tego, jak osiągnięcia różnych kultur niekiedy ścierają się, a innym razem przenikają, co prowadzi do rozwiązań i efektów nierzadko zaskakujących, należy niewątpliwie uznać za jeden z przywilejów życia w początkach XXI stulecia.

\section{BIBLIOGRAFIA}

Bal-Woźniak T., Woźniak M.G., Gospodarka Polski 1990-2011. Transformacja. Modernizacja. Spójność społeczno-ekonomiczna. Synteza, „Nierówności Społeczne a Wzrost Gospodarczy” 2011, z. 21, Uniwersytet Rzeszowski i Uniwersytet Ekonomiczny w Krakowie, Rzeszów-Kraków.

Barber B.R., Skonsumowani. Jak rynek psuje dzieci, infantylizuje dorostych i potyka obywateli, przeł. H. Jankowska, Warszawskie Wydawnictwo Literackie MUZA SA, Warszawa 2009.

Becker G.S., Treatise on the Family, Harvard University Press, Cambridge, MA-London 1993.

Bell D., Kulturowe sprzeczności kapitalizmu, przeł. S. Amsterdamski, Wydawnictwo Naukowe PWN, Warszawa 1998.

Berger P.L., Luckmann Th., Społeczne tworzenie rzeczywistości, przeł. J. Niżnik, Wydawnictwo Naukowe PWN, Warszawa 2010.

Berger P.L., Rewolucja kapitalistyczna, przeł. Z. Simbierowicz, Oficyna Naukowa, Warszawa 1995.

Bloch M., Parry J., Pieniadz i moralność wymiany, [w:] Badanie kultury. Elementy teorii antropologicznej, red. M. Kempny, E. Nowicka, Wydawnictwo Naukowe PWN, Warszawa 2005.

Boulding K.E., Etyka i biznes, [w:] Ponad ekonomia, red. i przeł. J. Grosfeld, PIW, Warszawa 1985.

Castells M., Społeczeństwo sieci, przeł. M. Marody i in., Wydawnictwo Naukowe PWN, Warszawa 2007.

Delsol Ch., Esej o człowieku późnej nowoczesności, przeł. M. Kowalska, Znak, Kraków 2003.

Ehrlich I., Lui F.T., Social Security, the Family, and Economic Growth, "Economic Inquiry” 1998, vol. XXXVI, July.

Etzioni A., For a Soft Moral Culture, „Kettering Review” 2001, vol. 19, no. 2, http:// www.gwu.edu/ ccps/etzioni/A285.pdf [dostęp: 2.10.2012].

Goody J., Kapitalizm i nowoczesność, przeł. M. Turowski, Wydawnictwo Akademickie Dialog, Warszawa 2006.

Goody J., Kradzież historii, przeł. J. Dobrowolski, Wydawnictwo Naukowe PWN, Warszawa 2009. 
Hirszowicz M., Stąd, ale dokąd? Społeczeństwo u progu nowej ery, Wydawnictwo Sic!, Warszawa 2007.

Inglehart R., Baker W.E., Modernization, Cultural Change, and the Persistence of Traditional Values, „American Sociological Review” 2000, vol. 65, no. 1, February.

Kochanowicz J., Trendy cywilizacyjne, [w:] Wymiary życia społecznego. Polska na przełomie XX i XXI wieku, red. M. Marody, Wydawnictwo Naukowe Scholar, Warszawa 2002.

Kopania J., Między buddyzmem a islamem, czyli przedwczesność chrześcijaństwa, [w:] Ekofilozofia, bioetyka, etyka biznesu. Aktualne problemy wspótczesności, red. J. Jaroń, Wydawnictwo Akademii Podlaskiej, Siedlce 2004.

Kopytoff I., Kulturowa biografia rzeczy - utowarowienie jako proces, [w:] Badanie kultury. Elementy teorii antropologicznej, red. M. Kempny, E. Nowicka, Wydawnictwo Naukowe PWN, Warszawa 2005.

Krzysztofek K., Cywilizacja: dwie optyki, Instytut Kultury, Warszawa 1991.

Landes D.S., Bogactwo i nędza narodów. Dlaczego jedni sa tak bogaci, a inni tak ubodzy, przeł. H. Jankowska, Warszawskie Wydawnictwo Literackie MUZA SA, Warszawa 2000.

Michalski M.A., Dzieci rynku... Rynek dzieci... Osoby czy zasoby?, [w:] Annales. Etyka w życiu gospodarczym, t. 15, Salezjańska Wyższa Szkoła Ekonomii i Zarządzania, Łódź 2012.

Morrison P.A., Demographic Links to Social Security, "Challenge” January-February 1982.

Pipes R., Własność a wolność, przeł. L. Niedzielski, MUZA SA, Warszawa 2000.

Radomski A., Dyskurs kulturoznawczy a kultury wspótczesnych społeczności, „Kultura Współczesna" 2007, nr 1(51).

Smith P.B., Max-Neef M., Economics Unmasked. From Power and Greed to Compassion and the Common Good, Green Books, Devon 2011.

Sosenko K., Ekonomia w perspektywie aksjologicznej, Wydawnictwo Akademii Ekonomicznej w Krakowie, Kraków 1998.

The Relationship Between Demographic Change and Economic Growth in the EU, eds A. Prskawetz, T. Lindh, Research Report 32, Vienna Institute of Demography, July 2007.

de Soto H., Rynek działa tylko na Zachodzie, przeł. Ł. Sommer, "Gazeta Wyborcza" 18.01.2001.

Sójka J., Kulturoznawca w świecie gospodarki, „Kultura Współczesna” 2008, nr 1(55).

Szlendak T., Socjologia rodziny. Ewolucja, historia, zróżnicowanie, Wydawnictwo Naukowe PWN, Warszawa 2010.

Sztaudynger J.J., Zatoń W., Kryzys gospodarczy a kryzys rodziny - analizy symulacyjne, „Prakseologia” 2010, nr 150.

Sztompka P., Socjologia. Analiza społeczeństwa, Znak, Kraków 2005.

Weber M., Gospodarka i społeczeństwo. Zarys socjologii rozumiejącej, przeł. D. Lachowska, Wydawnictwo Naukowe PWN, Warszawa 2002.

Weber M., Osobliwości kultury zachodniej, [w:] idem, Szkice z socjologii religii, przeł. J. Prokopiuk, H. Wandowski, Książka i Wiedza, Warszawa 1984.

Woods T.E. Jr., Jak Kościót katolicki zbudował zachodnia cywilizacje, przeł. G. Kucharczyk, Wydawnictwo AA, Kraków 2006.

World Bank, http://data.worldbank.org/indicator/NY.GDP.MKTP.CD [dostęp: 17.01.2014].

World Bank, http://data.worldbank.org/indicator/SP.DYN.TFRT.IN [dostęp: 17.01.2014].

Zakaria F., Koniec hegemonii Ameryki, przeł. S. Kroszczyński, Media Lazar NADIR, Warszawa 2009. 